\section{Forage and Serum Phosphorus Values for Bighorn Sheep ${ }^{1}$}

DARYLL M. HEBERT

Department of Zoology, University of British Columbia,
Vancouver, B. C., Canada.

\section{Highlight}

Total phosphorus values were determined monthly for winter and summer range forages in the East Kootenay Region of British Columbia. Phosphorus was high in succulent growing forages from both ranges but declined during the seed head and cured stages. The major decline for phosphorus in winter range forage was $57.1 \%$ during late summer. Serum inorganic phosphorus values for bighorn sheep were between 4.73 and $5.08 \mathrm{mg}$ percent during the winter period, when plant phosphorus was between 500 and 800 ppm.

The annual cycle of phosphorus in native range plants used by domestic livestock has been reported

${ }^{1}$ Study supported by National Research Council. Reccived May 27, 1971. upon by Watkins (1943); Watkins and Knox (1945); Knox et al. (1941); Johnston and Bezeau (1962); and Johnston et al. (1968). Watkins and Knox (1945) and Knox et al. (1941) have related serum inorganic phosphorus values in range cattle to phosphorus content of the forage. They indicate that phosphorus requirements are met only during the growing period.

The phosphorus requirements of bighorn sheep (Ovis canadensis canadensis) vary throughout the year similar to that described for domestic animals. Thus, the requirements change as an animal proceeds through an annual cycle (the growing and/or fattening period during May through October, the breeding period in November and December and the gestation and lactation period for some of the females during December through July). There has been increasing speculation concerning the adequacy of ranges to provide phosphorus during the gestation and lactation period of the annual cycle 


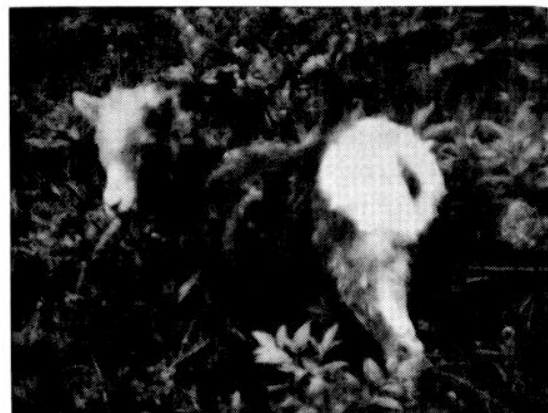

FIG. 1. An imprinted bighorn lamb used to determine food habits.

(Demarchi, 1968; Watkins, 1937; Johnston et al. 1968).

This paper examines the relation between serum and forage phosphorus during the winter and gestation periods using requirement values established for domestic animals.

\section{Methods}

These results are taken from a larger study which analyzed the benefits of altitudinal migration to a bighorn sheep population. One group of sheep was maintained on winter range forage year-round (control) while the other was shifted

Table 1. Seasonal changes in the phosphorus content (ppm) of winter and summer range forages.

\begin{tabular}{|c|c|c|c|}
\hline Range & $\begin{array}{l}\text { Date of forage } \\
\text { collection }\end{array}$ & Total phosphorus & $\begin{array}{c}\text { Decline between } \\
\text { collection } \\
\text { periods }(\%)\end{array}$ \\
\hline Winter & April 5-10 & 2500 & \\
\hline Winter & April 15-20 & 2600 & \\
\hline Winter & May $10-15$ & 2100 & 19.2 \\
\hline Winter & May $15-25$ & 1900 & 9.5 \\
\hline Winter & July $1-7$ & 1500 & 21.0 \\
\hline Winter & $\begin{array}{l}\text { July } 10-20 \\
\text { to }\end{array}$ & & \\
\hline Winter & Aug. $10-20$ & 1400 & 6.6 \\
\hline Winter & Sept. $15-20$ & 600 & 57.1 \\
\hline Winter & Oct. 9 & 800 & \\
\hline Winter & Oct. 10 & 600 & \\
\hline Winter & Oct. 15 & 800 & \\
\hline Winter & Oct. $20-25$ & 600 & \\
\hline Winter & March 6-30 & 500 & \\
\hline Total & & & 81.0 \\
\hline Subalpine & July $1-7$ & 1700 & \\
\hline Alpine & July $10-15$ & 3000 & \\
\hline Alpine & Aug. $10-20$ & 3000 & \\
\hline Alpine & Sept. $20-25$ & 1300 & \\
\hline Alpine & May 18 & 1300 & \\
\hline $\begin{array}{l}\text { Maximum to } \\
\text { minimum }\end{array}$ & & & 56.6 \\
\hline
\end{tabular}

Fig. 2. Typical alpine range used by bighorn sheep. from winter to summer and back to winter range forage (experimental) in order to simulate the natural migratory pattern. The control group contained two yearling females while the experimental group contained two yearling females and a yearling male.

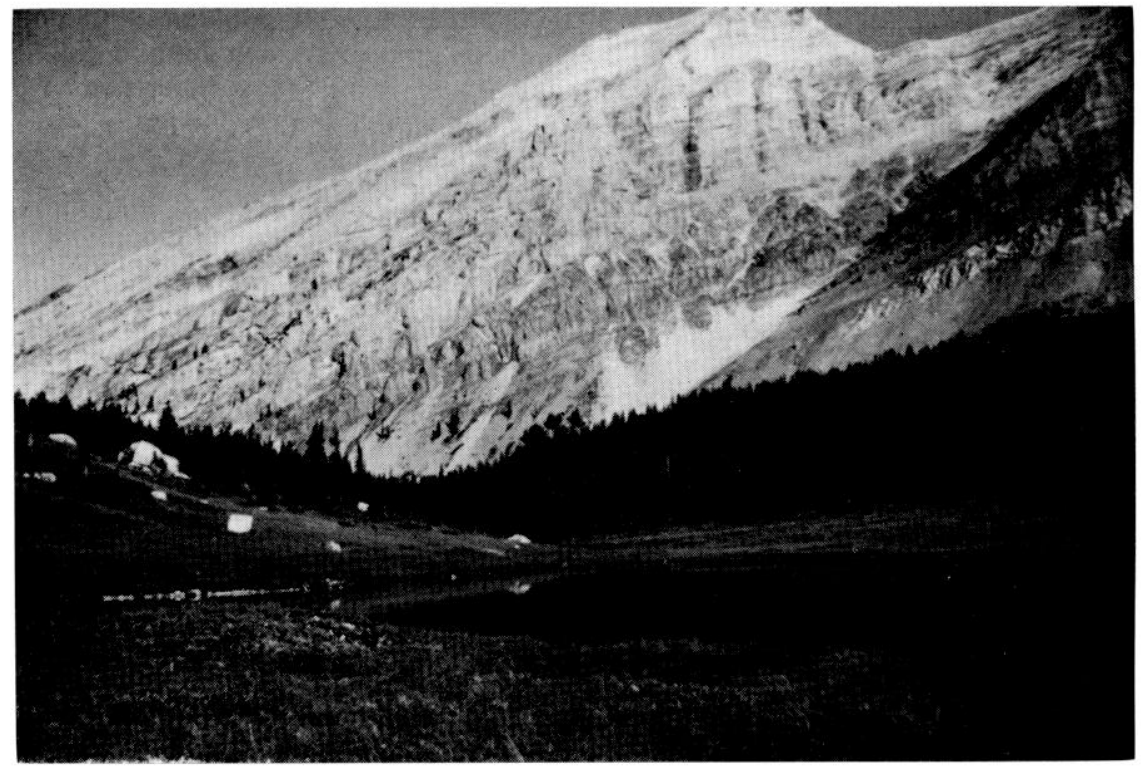




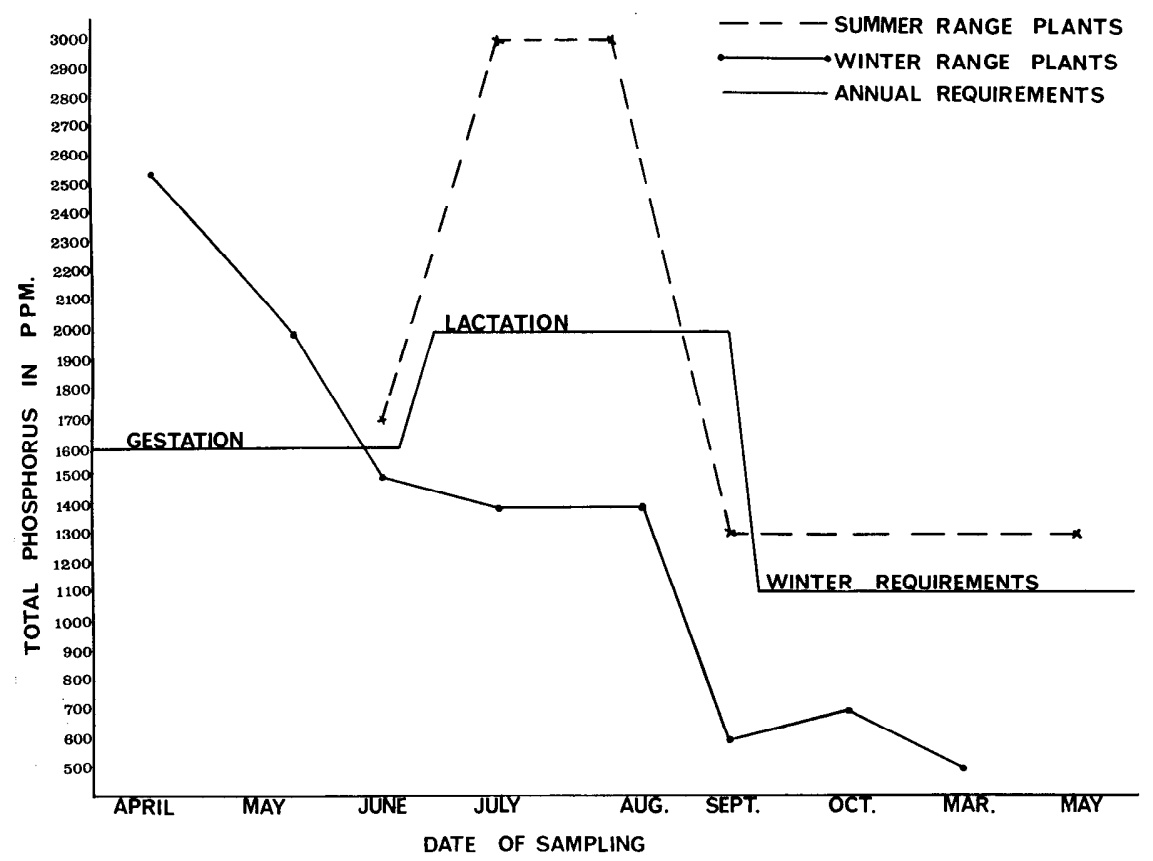

Fig. 3. The annual cycle of total phosphorus in winter and summer range plants, 1969-70.

values obtained from the winter ranges and alpine summer ranges (Fig. 2) is depicted in Figure 3. The samples upon which these comparisons are made were taken monthly between April 1969 and March 1970.

The phenological stage at each cutting date is presented in Tables 2 and 3 along with the approximate forage and percent composition of each diet. Bluebunch wheatgrass (Agropyron spicatum) comprises at least 75 percent of each winter range diet collected between April and September 20 as well as that cut during March 6-30. The diet cut October 9 contained only 50 percent bluebunch wheatgrass. The remaining portion of each of the above grass diets consisted of fescue (Festuca spp.), Junegrass (Koeleria cristata), pinegrass (Calamagrostis rubescens) and needlegrass (Stipa spp.). These species formed the grass portion of the diet when no bluebunch wheatgrass (October 10 and 15) was present. A diet consist-

Table 2. The approximate phenology and composition (\%) of the natural diets cut on the Premier Ridge winter range.

\begin{tabular}{llccc}
\hline \hline \multirow{2}{*}{$\begin{array}{c}\text { Date of } \\
\text { forage } \\
\text { collection }\end{array}$} & $\begin{array}{c}\text { Approximate } \\
\text { phenology }\end{array}$ & \multicolumn{3}{c}{ Composition of diet } \\
\cline { 3 - 5 } & Grass & Forbs & Browse \\
\hline April 5-10 & New growth & 100 & 0 & 0 \\
April 15-20 & New growth & 99 & .5 & .5 \\
May 10-15 & Third leaf & 90.9 & 8.2 & .9 \\
May 15-25 & Fourth leaf & 94.7 & 0 & 5.3 \\
July 1-7 & Seeds ripe & 88.2 & 7.1 & 4.7 \\
July 10-20 & Seeds shedding & 88.1 & 7.2 & 4.7 \\
$\quad$ to & & & & \\
Aug. 10-20 & Cured & 90.0 & 7.0 & 3.0 \\
Sept. 15-20 & Cured & 95.0 & 4.0 & 1.0 \\
Oct. 9 & Cured & 90.1 & 6.8 & 3.1 \\
Oct. 15-20 & Cured & 92.0 & 2.0 & 6.0 \\
Oct. 20-25 & Over-wintered & 95.0 & 2.0 & 3.0 \\
March 6-30 &
\end{tabular}

ing of mainly Kentucky bluegrass (Poa pratensis) was collected during October 20-25.

The presentation of diets in this order allowed a preliminary examination of the potential of bluebunch wheatgrass to supply phosphorus to a wild ungulate.

The subalpine and alpine mixtures were categorized only as grasses and sedges, forbs and shrubs (Table 3).

Maximum phosphorus valucs of winter range grasses, mainly bluebunch wheatgrass and fescue, reached 2600 to $2800 \mathrm{ppm}$ in April but had declined to $1600 \mathrm{ppm}$ by early July. Decline was abrupt between July and September, with a total decline for the period of about $57 \%$. Late winter values of 500 ppm represented about an $81 \%$ loss from maximum values, the previous spring. Declines are minimal from early to late winter, during the period when forage is frozen. The phosphorus content of the grass mixtures fed during this period ranged between 500 and 800 ppm. There appeared to be no significant differences in the phosphorus content, between diets, as the quantity of bluebunch wheatgrass declined from $75 \%$ to 0 .

The alpine forage, with its later commencement of growth, reached maximum levels toward the end of July (3000 ppm) and maintained these throughout August. By freeze-up in late September values had declined by $56 \%$ to 1300 ppm. The May value represents the yearold growth as first exposed after snow melt in the spring or as taken from beneath the snow cover. The much reduced decline during winter freeze-up is comparable to that found on the winter range. In September, the phosphorus values of alpine vegetation are about twice those of the corresponding winter range vegetation and during late winter they are two to three times greater. The maximum levels of phosphorus in alpine forage and seasonal declines, encountered in this study, were similar to those found by Johnston et al. (1968), working in Alberta. 
Table 3. The approximate phenology and composition $(\%)$ of the natural diets cut on subalpine and alpine range.

\begin{tabular}{llllll}
\hline \hline \multirow{2}{*}{$\begin{array}{l}\text { Date of } \\
\text { forage } \\
\text { collection }\end{array}$} & Area & Approximate phenology & $\begin{array}{c}\text { Grass \& } \\
\text { sedge }\end{array}$ & Forbs & Browse \\
\hline July 1-7 & Subalpine & Late leaf to flower & 41.7 & 50.4 & 7.9 \\
July 10-15 & Alpine & New growth & 49.3 & 50.7 & 0 \\
Aug. 10-20 & Alpine & Flower to seed stage & 56.4 & 34.8 & 0 \\
Sept. 20-25 & Alpine & Plants frozen & 85.0 & 15.0 & 0 \\
May 18 & Alpine & Over-wintered & $50-60$ & $40-50$ & 0 \\
\hline
\end{tabular}

As shown in Figure 3, the minimum level required for gestating domestic ewes is $1600 \mathrm{ppm}$ or $.16 \%$, as set by the National Research Council (1964). They suggest that lactating ewes require $.20 \%$ phosphorus. Watkins (1943) gives .093\% as the minimum winter requirements for range cattle.

Winter range forage meets the phosphorus requirements for gestation during the latter half of the gestation period. It appears inadequate during lactation. If bighorn ewes migrate to alpine areas during lactation, they appear to receive adequate phosphorus. The alpine summer range provides adequate amounts of phosphorus for winter requirements (certain bands of bighorn sheep remain on alpine ranges year-round) whereas the winter range does not.

Blood sampling began October 1, 1969, and was performed monthly until May 1970. Serum phosphorus values for this period are given in Table 4.

The initial blood sample was taken on October 1 while the experimental group was on alpine forage and the control group on winter range forage. The experimental group showcd a serum phosphorus value of $6.26 \mathrm{mg}$ percent while on forage containing 1300 ppm phosphorus. The control group showed a value of $6.64 \mathrm{mg}$ percent while on forage containing 600 ppm phosphorus. Thus, although forage phosphorus differed by about 54 percent serum phosphorus values were similar, averaging $6.45 \mathrm{mg}$ percent.

During the winter months, both groups subsisted on winter range forage containing 500 to $800 \mathrm{ppm}$ phosphorus. Serum phosphorus declined to 5.08 and $4.73 \mathrm{mg}$ percent for the experimental and control groups, respectively. Simesen (1963), states that scrum inorganic phosphate concentration in normal adult animals is $4-7 \mathrm{mg} / 100 \mathrm{ml}$.

During early spring (May, 1970), both groups were placed on an artificial pelleted ration (ration 3657) containing 6600 ppm phosphorus. Serum inorganic phosphorus rose to an average of 9.95 mg percent (Table 4).

There appears to be a direct relationship between serum and forage phosphorus during the winter months. According to the correlation coefficient of .885 the variables are significantly related $(\mathrm{P}=.0015)$. Knox et al. (1941) gives a correlation of .6102 \pm .0646 between forage and serum phosphorus of cattle, during an annual cycle, indicating the usefulness of this relationship in the assess-

Table 4. Monthly serum inorganic phosphorus values $(\mathrm{mg} / 100 \mathrm{ml})$ for the control and experimental groups, 1969-70.

\begin{tabular}{llcc}
\hline \multirow{2}{*}{$\begin{array}{c}\text { Date of blood } \\
\text { sampling }\end{array}$} & $\begin{array}{c}\text { Date of forage } \\
\text { collection }\end{array}$ & Serum phosphorus \\
\cline { 3 - 4 } & Control group & Experimental group \\
\hline Oct. 1 & Sept. 15-20 & 6.64 & 6.26 \\
Dec. 3 & Oct. 9 & 3.63 & 3.90 \\
Dcc. 29 & Oct. 10 & 4.35 & 5.50 \\
Jan. 19 & Oct. 15 & 5.05 & 4.80 \\
Feb. 11 & Oct. 20-25 & 5.60 & 5.80 \\
March 4 & Oct. 20-25 & 5.50 & 4.70 \\
April 13 & March 6-30 & 1.30 & 5.80 \\
May 20 & Ration $36-57$ & 10.30 & 9.60 \\
N. & & 14 & 21 \\
Mean (not incl. & & & 5.25 \\
ration 36-57.) & & 5.04 & \pm .7 \\
S.E. & & \pm 1.3 & \\
\hline
\end{tabular}

ment of the phosphorus nutrition of an animal.

Kleiber et al. (1936) shows that cattle on a high phosphorus diet have high serum phosphorus levels (8.27 to $9.79 \mathrm{mg}$ percent) and low serum phosphorus values (3 to 5 mg percent) on a low phosphorus diet.

Franzmann and Thorne (1970) give a serum phosphorus value of $3.9 \pm 1.1 \mathrm{mg}$ percent for 6 bighorn sheep captured in Wyoming during March. This value is only slightly below that obtained in this study (5.10 $\mathrm{mg}$ percent) during the same month. According to Long et al. (1965) and Knox et al. (1941) serum inorganic phosphorus is slightly higher in young animals, which may account for the difference between my sheep and those of the above authors.

\section{Conclusions}

The alpine ranges supply sufficient quantities of phosphorus year-round according to the requirements of domestic animals. Although scattered populations of bighorn sheep remain on these ranges throughout the year it is unlikely that herd numbers can be increased on these ranges during the winter months. The adjacent winter range appears adequate only during the growing period (April to July). Also, blucbunch wheatgrass did not provide significantly greater quantities of phosphorus 
than any of the other grass mixtures when collected in the cured stage.

Since aphosphorosis did not occur during the winter blood sampling period, phosphorus accumulated during the growing period on winter and alpine ranges may influence blood phosphorus during the winter when forage phosphorus is in short supply. At this time it is not known to what degree a free-ranging animal can accumulate phosphorus (April to October) nor the ease with which it is mobilized from storage depots. Simesen (1963) states, "Bone mineral is readily mobilized to maintain the level of serum calcium, but less readily to maintain that of phosphorus, so that a low serum inorganic phosphate level is the first sign of a deficiency of phosphorus." Hays and Swenson (1970) suggest that bone phosphorus is readily mobilized.

Serum inorganic phosphorus levcls of my shcep did not indicate a state of deficiency. They were above $4 \mathrm{mg} / 100 \mathrm{ml}$, the minimum level set by the National Research
Council (1964) and Watkins and Knox (1945).

\section{Literature Cited}

Demarchi, R. A. 1968. Chemical composition of bighorn winter ranges. J. Range Manage. 21:385-388.

Franzmann, A. W., and E. T. Thorne. 1970. Physiologic values in wild bighorn sheep (Ovis canadensis canadensis) at capture, after handling, and after captivity. J. Amer. Vet. Med. Ass. 157:647-650.

Hays, V. W., and M. J. Swenson. 1970. Minerals. From Dukes' physiology of domestic animals. Edit. M. J. Swenson. Comstock Publishing Associates. Ithaca, N.Y.

Johnston, A., And L. M. Bezeau. 1962. Chemical composition of range forage plants of the Festuca scabrella association. Can. J. Plant Sci. 42:105-115. Johnston, A., L. M. Bezeau, And S. SMoliak. 1968. Chemical composition and in vitro digestibility of alpine tundra plants. Jour. Wildl. Manage. 32:773-777.

Kleiber, M., H. Goss, and H. R. GuilBERT. 1941. Seasonal calcium and phosphorus requirements of range cattle, as shown by blood analyses. New Mexico College of Agriculture and Mechanic Arts. Agr. Expt. Sta. Bull. No. 282.

Long, C. H., D. E. Uli.rey, E. R. MilLER, B. H. ViNCENT AND C. L. ZuTAuT. 1965. Sheep hematology from birth to maturity. Scrum calcium, phosphorus, magnesium, sodium and potassium. J. Anim. Sci. 24:145-150.

National Research Council. 1964. Committee on animal nutrition. Nutrient requirements of domestic animals. No. 5. Nutrient requirements of sheep. National Academy of Sciences, Wash., D.C. Pub. 1193.

Simfsen, M. G. 1961. Calcium, inorganic phosphorus, and magnesium metabolism in health and disease. From Clinical biochemistry of domestic animals. Edit. C. E. Cornelius and J. J. Kaneko. Academic Press. New York.

Watkins, W. E. 1943. The composition of range grasses and browse at varying stages of maturity. New Mexico College of Agriculture and Mechanic Arts. Agr. Exp. Sta. Bull. No. 311.

Watkins, W. E., and J. H. Knox. 1945. The monthly protein and phosphorus contents of two important range grasses of southern New Mexico. J. Anim. Sci. 4:297-305. 